\title{
A Perspective of Microinsurance (MI): The Case of South Africa
}

\section{B. Zaheenah Chummun}

School of Accounting, Economics and Finance, University of KwaZulu-Natal Westville Campus Private Bag X54001, Durban 4000, South Africa \& PhD student at the Potchefstroom Business School, North-West University, South Africa Email: zaina.khan499@gmail.com

\section{Christo A Bisschoff}

Potchefstroom Business School, North-West University, Private Bag X6001, Potchefstroom, 2520, South Africa

Email: christo.bisschoff@nwu.ac.za

\section{Doi:10.5901/mjss.2014.v5n23p63}

\section{Abstract}

Microinsurance (MI), an important economic roleplayer, is investigated in and placed in perspective to the insurance industry in South African. This is achieved by researching the factors that cause serious deprivation in the provision of MI. Typical restrictive factors are financial literacy, out-of-reach of customers, and low commission for brokers. Resultantly, the need for stakeholder analysis presents itself to better understand and address these challenges which should enable an up-and-running MI environment in South Africa. Historically, the insurance industry focussed on financial products and services that for the middle to high income groups. The low-income households have thus been largely excluded from insurance benefits although the consequences of setbacks are extreme for the low income group. As a result, the market most vulnerable to financial shocks are the least protected. This situation has drastically changed during the last few years. The LOASA and the Insurance companies reached consensus with the Financial Sector Charter of South Africa to launch tailor-made products and services for the low-income people. South Africa is still facing an "Insurance Gap", approximately $61 \%$ of the low-income households which are not insured represent a huge opportunity for the industry. Therefore, the introduction of the Zimele products classified as MI products in 2007 was a good launch to target the "niche" of those uninsured market.

Keywords: Zimele - MI Product, low-income households, vulnerable, LSM 1-5, financial shocks.

\section{Introduction}

The South African population currently exceeds 50 million (Index Mundi and Statistics South Africa, 2013), and according to the Association for Savings and Investment South Africa Insurance Gap Study (ASISA, 2013), approximately 61\% of the low-income households do not have any life and disability insurance to safeguard them against hardship. Resultantly, an "insurance gap" consisting of low-income households (those earning less than R3000 a month and who belong to the Living Standard Measure one to five (LSM 1-5) group realizes almost 20 million households (Institute International Research, 2013). The 2013 insurance gap, which is the difference between existing life and disability cover and the actual insurance need of South African low-income earners, widened to a staggering R24 trillion compared to R18.4 trillion in 2010 and R10 trillion in 2007 (Dempsey, 2013). Table 1 illustrates the increase in insurance gap from 2010 and 2013.

Table 1: Increase in Insurance Gap 2010-2013

\begin{tabular}{|l|c|c|c|c|}
\hline \multicolumn{1}{|c|}{ R Trillion } & $\mathbf{2 0 1 0}$ Insurance Gap & $\mathbf{2 0 1 0}$ Insurance Gap & 2013 Insurance Gap & 2013 Insurance Gap \\
\hline & Death & Disability & Death & Disability \\
\hline Insurance Need & 11,683 & 18,714 & 15,146 & 24,435 \\
\hline Actual Cover & $-4,426$ & $-5,563$ & $-5,867$ & $-7,280$ \\
\hline Disability Grant Cover & & 2,014 & & 2,414 \\
\hline Insurance Gap & 7,257 & 11,137 & 9,279 & 14,741 \\
\hline Gap as a \% of Need & $62 \%$ & $60 \%$ & $61 \%$ & $60 \%$ \\
\hline
\end{tabular}

Source: True South Actuaries and Consultants (2013) 
FinScope South Africa (2013) further adds that, in terms of household density, there are on average five people per household in South Africa in the category, but indicates that in the case of the poor, the family density exceeds this average and that they are most likely to have much larger households. The fact that the majority of these households are not insured; represents a market opportunity for the South African Ml industry.

Microinsurance refers to insurance that is accessed by the low-income population (also known as the mass market), provided by a number of different providers and managed in accordance with generally accepted insurance practices. It forms part of broader insurance market, distinguished by particular low-market market segment focus (National Treasury of South Africa, 2011).

Although microinsurance is mainly targeted at the low-income market with irregular income, the products also aim at providing cover to those that have a stable (but small) income. These insurance policies that target the poor in South Africa are branded as Zimele policies, and are classified as typical microinsurance products (Association of Savings and Investments South Africa, 2009). The first Zimele stamped product was funeral cover. The product was fully adopted by the low-income market, and it dominates the market (Smith, Chamberlain, Hougaard, Carlman and Smit, 2010). According to the 2012 report on Landscape of Microinsurance in Africa by McCord, Steinman, Jaleran, Ingram and Mateo (2012), other microinsurance products such as agriculture, health and insurance of assets are not adopted by the market yet. A low level of market and financial awareness exist among these most vulnerable consumers who are more prone to unexpected events and risks, and yet they enjoy virtually no insurance protection (McCord et al., 2012).

The introduction of the Zimele-compliant microinsurance products and services by the LOASA 2007 in collaboration with the Government demonstrates the latter's eagerness to promote a microinsurance culture in the country. Since one of the Millennium Development Goals (MDGs) is to reduce poverty by $50 \%$ by 2015 in this regard, MI has been classified to be one of the most innovative financial tools to mitigate poverty and could be one vehicle used to persue the poverty alleviation goals (Tomchinsky, 2008; Microinsurance Network, 2013).

\section{Problem Statement}

The World Bank's Global Monitoring Report for 2010 estimates that the economic crisis left an estimated 50 million more people in extreme poverty in 2009 worldwide, with an additional 64 million who fell into extreme poverty by the end of 2010 relative to pre-crisis trends (World Bank, 2010). Poverty levels has also increased in South Africa have increased slightly over the last decade (Afrobarometer, 2013).The Afrobarometer poverty survey's Lived Poverty Index (LPI) for 2012 showed South Africa scoring 0.81 on a scale of zero to four. Four reflects a constant absence of all basic necessities, while zero reflects no poverty. In 2002, South Africa scored 0.71 . The years in between have been somewhat worse -0.82 in 2005, and 0.89 in 2008 on the LPI - but the slight improvement has not come close to full recovery to that level. The survey indicated that poverty in South Africa increased over the last decade despite reported average economic growth of 3.6\% between 2002 and 2012. Between 2011 and 2013, 60\% of South Africans never experienced water shortages, while $29 \%$ did so once, twice or several times. Eleven percent experienced water shortages many times (Afrobarometer, 2013).

Further according to Stats SA Living Conditions Survey, poverty levels in South Africa decreased between 2000 and 2006, but increased between 2006 and 2009 (StatsSA, 2011). For example, using the values (unadjusted for food based on actual rentals) from the IES 2005/2006 (column C) and LCS 2008/2009 (column D), the poverty headcount has increased from $24.8 \%$ to $36.9 \%$ based on the food poverty line. 
Table 2: Increase in poverty headcount in South Africa by year

\begin{tabular}{|c|c|c|c|c|c|c|c|}
\hline A & B & C & D & E & $\mathbf{F}$ & $\mathbf{G}$ & $\mathrm{H}$ \\
\hline 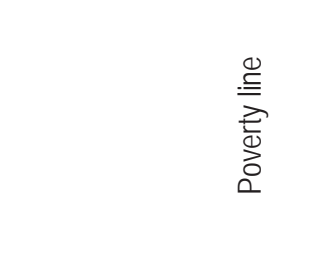 & 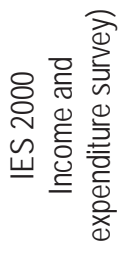 & 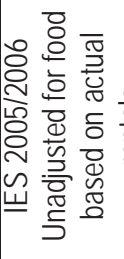 & 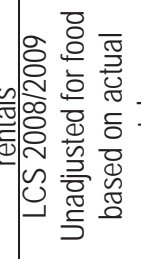 & 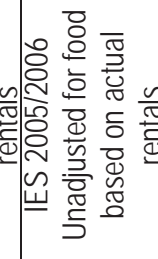 & 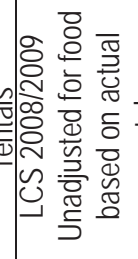 & 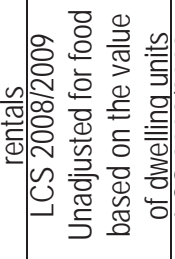 & 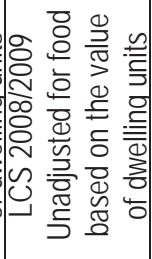 \\
\hline Food poverty line* & R148 & R209 & R305 & R209 & R305 & R305 & R305 \\
\hline Poverty headcount & $28.5 \%$ & $24.8 \%$ & $36.9 \%$ & $21.7 \%$ & $29.9 \%$ & $26.3 \%$ & $32.4 \%$ \\
\hline Lower-bound poverty line & R219 & R298 & R416 & R298 & R416 & R416 & R416 \\
\hline Poverty headcount & $43.5 \%$ & $40.1 \%$ & $48.9 \%$ & $36.7 \%$ & $7 \%$ & $42.9 \%$ & $38.9 \%$ \\
\hline Upper-bound poverty line & R323 & R428 & R577 & R428 & R577 & R577 & R577 \\
\hline Poverty headcount & $57 \%$ & $54.7 \%$ & $60 \%$ & $51.9 \%$ & $55.6 \%$ & $52.3 \%$ & $56.8 \%$ \\
\hline
\end{tabular}

* Exchange rate: $1 \$$ US approximately resembles 1 South African Rand (R)

Source: Statistics South Africa (2011)

The World Bank (2012) reports that inadequate access of basic cover by the poor, is a major cause of poverty in developing countries. With a population of more than 50 million people, $44.6 \%$ consumed less than the "lower-bound" poverty line (those earning less than R3000 per month), South Africa is categorized by the World Bank as among the poor countries in the world (Index Mundi, 2013). The economy has been experiencing slow growth while the disparity between the rich and the poor continue to widen. The result of slow economic growth is characterized by widespread inflation, unemployment and high levels of poverty where over two-third of human beings suffering from extreme poverty are women who manage to survive on approximately $1 \$$ US a day (Oxfam, 2013).

South Africa's development challenge, therefore, remains in finding sustainable poverty eradication strategies and one of the main objectives of Millennium Development Goals (MDGs) is to half poverty by 2015. Poor people are more likely to live and work in risky environments and also are portrayed to be more vulnerable to illness, accidents, loss of property due to theft or fire, agricultural losses, and natural and man-made disasters (Oxfam GB, 2012). Not only can exposure to these risks result in substantial financial losses, but vulnerable households suffer from the ongoing uncertainty about whether and when a loss might occur. The poor are less likely to take advantage of income-generating opportunities that might reduce poverty because of this perpetual apprehension (Banerjee, 2008). Although there is little evidence-based knowledge of the impact of microinsurance on poverty reduction, microinsurance can help reduce the vulnerability that poor households face and as a consequence, enable the poor to improve their lives.

In this regard, Ml has been identified as one possible financial tool to address poverty (Microinsurance Network, 2013). However, very little research has been done in the field of MI in South Africa and how these products in the insurance industry can service the goals of poverty alleviation. In addition, MI as integral part of insurance, has not been placed into perspective, not properly described, nor has it been substantialised within the insurance industry as (viable) separate business entity.

\section{Objectives}

The primary objective of this article is to investigate microinsurance in perspective to the insurance industry and as a role player in the South African economy.

This primary objective is achieved by addressing the following secondary objectives:

- Introduce and explain the concept of microinsurance;

- Discuss the role and importance of microinsurance in the economy;

- Determine and discuss the challenges posed to microinsurance; and to

- Make recommendations to the microinsurance industry based on the literature review.

\section{The Role and Importance of Microinsurance}

Financial exclusion has been a topic of interest on the agenda that has dominated the financial services sector of South 
Africa for a while. Too many South Africans remain excluded from formal financial services Treasury (National Treasury of South Africa, 2011). For this reason the National Treasury has prioritized access to financial services as an important objective in the sector reform (National Treasury of South Africa, 2011). In 2004, this was a key objective in the Financial Sector Charter resulting in the Mzansi banking accounts initiative which provided access to many previously unbanked people. The challenge of inclusion is proving to be more in the insurance sector. This is evidenced by the low number of South Africans covered by insurance falling in the category of mass market. To add to that, the element of risk is more likely to be present in the lives of the poor as most of them live in insecure conditions, for example shacks (their houses) are more prone to fire and other allied perils (Churchill and Matul, 2012, p.23). The break-out of the fire in Devland informal settlement in the South of Johannesburg, South Africa in January 2014 drew on the low-income earners financial, physical, social and human assets to meet the resulting expenses (Mulaudzi, 2014). In the absence of precautionary instruments such as MI, most were forced to borrow money or looked for help from others as few lowincome earners have access to formal insurance services.

As one of the main Millennium Development Goals (MDGs) set by the United Nations Development Programme in 2005 is to eradicate extreme poverty and hunger by year 2015 that respond to the world's main development challenges (United Nations Development Programme, 2005), therefore the role of microinsurance by bringing financial inclusion to the financially excluded ones, can contribute to achieving the main Millennium Development Goals (United Nations Development Programme, 2013).

Further among others, $\mathrm{Ml}$ is also important for the following reasons:

\subsection{Microinsurance promotes gender equality}

Research reveals that poor men are confronted with many of the poor households and vulnerable risks (Churchill et al., 2012). However, the impact on poor women is far greater. Globally, women account for 70 per cent of the world's poor (United Nations Entity for Gender Equality and the Empowerment of Women, 2010). They earn less income, often from informal sector employment, with less ownership and control of property (Brown and Churchill, 1999; Mayoux, 2002). When these vulnerabilities are combined with the responsibility of ensuring the welfare and security of their families, it is clear that women not only have a unique and pressing need for appropriate means to manage risk, but also serve as agents for the risk management of their entire families. This can be substantiated by a report on "Making Microinsurance programs gender-sensitive" by Banthia, Johnson and McCord (2009) where the authors speak of the disproportionate levels of physical vulnerability and violence faced by women and children. Churchill $(2006$, p.130) also put forward that they face more abuse and exploitation than men, such as forced prostitution, battery and extreme cruelty or exploitative domestic servitude. This greater vulnerability contributes to strong risk adverse behaviour (Churchill, 2006, p.131).

However, Banthia et al. (2009) adds that some of these risks can be improved through microinsurance, for example: health risk and life cycle risks which can be catered through the provision of health care and life assurance respectively. An analysis of current microinsurance reveals that some progress is being made to reduce the vulnerability of women and children (Churchill, 2006, p.134). In designing health care schemes, microinsurers need to ensure that they cater for women health concerns especially those related to pregnancy, delivery and maternity, gynaecological diseases and HIVIAIDS (Churchill et al., 2012).

Microinsurance is a new frontier of development, and there is much work to be done to create a gender-sensitive microinsurance industry. It is crucial to further develop an understanding of how women combine microinsurance with existing risk management strategies, how their attitudes to risk differ from those of men, and how microinsurance affects their rates of investment into businesses, savings behaviour and household consumption. Donors, researchers and practitioners each have an important role to play in creating a coordinated effort to further the development of gendersensitive microinsurance. (Churchill et al., 2012).

\subsection{Microinsurance provides sustainability}

Microinsurance needs scale and efficiency in order to be sustainable (Gray and Bel, 2010). Microinsurance represents a key tool for sustainable development with tremendous potential for mitigating risk factors to low-income households. With estimates that less than $5 \%$ of the world's poor benefit from insurance, these households remain highly susceptible to risks posed by a wide range of issues including sickness, loss of livestock and catastrophic climate events. A policy that offers value to the client requires that premiums remain low and benefits for policy holders as high as possible. On the other hand, insurers in this context need to reach large numbers of low-income clients to achieve profitability. To this end, creating economies of scale and promoting efficiency which can reduce administrative costs are critical issues 
(International Labour Organisation, 2010).

According to a joint report by insurers and the United Nations, $\mathrm{MI}$ is crucial to sustainable growth because it has the ability to engage the majority of the population in economic activities (UNEP FI, 2008). Maleika and Kuriakose (2012) further add that a flexible and powerful instrument, MI reduces vulnerability and mitigates the negative effects of external shocks on poor households. In this regard, it is important for the insurance industry to develop Ml products to promote sustainable growth in developing countries, (UNEP FI, 2008). The $\mathrm{MI}$ industry is also a strong lever for implementing sustainability due to its size, the extent of its reach into the community and the significant role it plays in the economy (Maleika et al., 2012).

While mainly a solution to social and economic vulnerability, microinsurance can also encompass environmental risk. One recent innovation identified is the use of simple weather derivatives to provide micro crop insurance to poor farmers. MI also helps poor communities cope with the effects of climate change. A major concern about climate change is that most of the economic losses from disasters are uninsured, leaving the victims to refinance themselves or rely upon donor aid. This is especially acute in developing countries where insurance penetration is very low (UNEP FI, 2008). Therefore $\mathrm{MI}$ is a method of insuring the poor, who are traditionally excluded from financial services and ultimately entails sustainability (ILO, 2010).

\subsection{Microinsurance entails social protection}

Access to social security is an international fundamental human right (Loewe, 2001). Moreover, social security and social protection are increasingly recognised in the global debate as indispensable components of poverty reduction, sustainable economic development, fair globalisation and decent work (Churchill et al., 2012). Social protection is a key tool for the attainment of the Millennium Development Goals to reduce poverty, inequality and vulnerability (Churchill et al., 2012). It promotes equity and solidarity through redistribution. However, more than half of the world's population does not benefit from any form of social protection (ILO, 2010).

$\mathrm{MI}$ can be an effective complement to existing menus of social protection programs. A flexible and powerful instrument, MI mitigates vulnerability and the negative effects of external shocks on poor households. However, MI programs require well-developed institutional arrangements in order to run in an efficient and effective manner. Such conditions can be difficult to find in low-income countries. Social funds can help bridge this gap, standing as a platform to organize and deliver Ml products (Maleika et al., 2012).

Facing exclusion from social protection, local communities are taking initiatives to organise microinsurance schemes for instance, health care schemes, for instance in Ghana, funeral societies cater for funeral cover through payment of small premiums from insureds since funerals are important and expensive social events (De Witte, 2003). In Sri Lanka, the government spent three percent of its Gross Domestic Product (GDP) on social protection in 2004 (ILO, 2010). Strategies and tools against social exclusion and poverty (STEP) has intervened in Benin since 2002; its main activities consist of the support to healthcare microinsurance schemes for the extension of social protection to informal economy population and, in general, for those who do not benefit from any social coverage. Therefore, from the above, it can be noted that microinsurance is an effective tool to promote social protection and can be used as an instrument to close the insurance gap of almost $61 \%$ of the low-income households that are not insured in South Africa (ASISA, 2013).

\subsection{Microinsurance contributes to the South African economy}

South Africa has a variety of microinsurance services available to the low-income groups (National Treasury of South Africa, 2011). These services are offered by a variety of formal and informal institutions (MFI's, retailers, agents, insurers, banks and brokers), and cover a spectrum of different insurables. The provision of microinsurance by formal sector institutions in particular sets South Africa apart from most other developing countries. South Africa thus presents a rich opportunity to study the microinsurance sector. (McCord et al. 2012). However, despite the evident need and role for microinsurance in South Africa, few South African MFIs presently supply microinsurance schemes.

Compared to the other developing countries, South Africa has a better-developed commercial microinsurance industry - primarily Zimele funeral insurance (National Treasury of South Africa, 2011). However, this industry is not without its challenges, discussed later in the paper. MI in South Africa is quite different from in the rest of the continent, in part because there is both a supply of and a demand for cover. Due to the high social and cultural value placed on dignified funerals, many low-income households have funeral insurance, even multiple policies. On the supply side, many South African insurers are sophisticated and entrepreneurial - the country has one of the highest penetration rates in the world (Swiss Re, 2011). The combination of sophisticated insurers and the demand from low-income households results 
in a growing and innovative market. In South Africa, under the Financial Sector Charter that encouraged insurers to go down-market, (approximately, US $\$ 300$ per month). The proportion of this population that has some form of risk cover (formal or informal) grew substantially from 33 per cent in 2006 to 38.5 per cent in 2010. This expansion was almost exclusively driven by an increase in formal funeral insurance. However, in absolute terms, the number of insured lives actually fell from just under 6.5 million in 2006 to just over 4.5 million in 2010 (Swiss Re, 2011). From 2006 to 2010, the population living below US $\$ 300$ per month fell from just over 19.5 million to less than 12 million people. Consequently, the drop in the number of persons covered in South Africa can be perceived as a positive development outcome (Smith et al., 2010).

\subsection{Microinsurance contributes to the global economy}

The number of people covered by microinsurance worldwide has increased substantially over the past five years; from 78 million in 2007 to 135 million in 2009, reaching nearly 500 million today and is expected to hit one billion by the end of the decade (Churchill et al., 2012). Since 2008, concerted efforts have emerged to overcome the challenges of providing viable insurance services to more low-income people during this economic turmoil, to eventually to promote the development and delivery of effective insurance services for low-income people (ILO, 2012). Efforts now should focus on increasing effectiveness so that insurance products can successfully reduce their vulnerability. The results show that Asia - with its two microinsurance powerhouses: China and India - is spearheading the trend, covering roughly 80 per cent of the market. It is estimated that 60 percent of people around the world who are covered by microinsurance live in India. Latin America accounts for 15 percent of the market and Africa 5 percent (ILO, 2012). There are many reasons why Asia is ahead of the game: large and dense populations, interest from public and private insurers, proper distribution channels and active government support are some examples (ILO, 2012).

Reinhard (2012) further adds that it is important that key stakeholders work together effectively. Microinsurance is unlikely to break the cycle of poverty by itself especially in the era of economic meltdown, but it is a valuable tool in the poverty alleviation toolkit. When coupled with social protection, risk prevention and mitigation, and supplemented by other risk-managing financial services such as savings and emergency loans, microinsurance can play a critical role at multiple levels to efficiently manage risks, reduce vulnerability and contribute to poverty alleviation (ILO, 2012).

The above literature has stressed the role and importance of microinsurance on both a national and international level front. The next section of the literature looks at the challenges posed by the Microinsurance industry.

\section{Important Challenges of MI}

\subsection{Understanding Microinsurance}

It is widely believed that low-income households do not understand insurance, for this reason they do not buy or renew (Matul, Dalal, De Bock and Gelade, 2013). Platteau and Uggarte (2013) add that people with a low level of understanding are less likely to renew, in fact below a certain level, nobody renewed the policy. One of the biggest challenges is to explain the concept and benefits of microinsurance to the low-income households. Insurance literacy is currently recognised as one of the most important hurdles to overcome. Educating the clients on the benefits of insurance is an indispensible ingredient to the success of any marketing actions undertaken by a microinsurance provider. In addition, the low-income households are generally faced with little awareness and lack of financial education (Microinsurance Network, 2010). Awareness of microinsurance among the illiterate and low income level market should be instilled. For example, Gaurav, Cole and Tobacman (2011) found that training had a varied impact on the purchase of agriculture insurance that South Africa does not have in its consortium of microinsurance products (McCord et al., 2012).

\subsection{Trust}

Engaging trust has been central to efforts by the financial services industry especially the insurance sector to win products for their markets (Matul et al., 2013). Cole, Stein and Tobacman (2011) highlighted evidence to show that building trust enhances the take up of an insurance product. Further, Dong, De Allegri, Gnawali, Souares and Sauerborn (2009) identified trust in the management of the community health scheme as an important factor influencing households' probability of enrolling.

Unlike the case in credit, where the micro-entrepreneur borrows the money and takes up the responsibility of returning it, insurance reverses the responsibility of risk (Microinsurance Network, 2010). In micro lending, the provider 
puts up the capital and trusts the customer to pay it back; in insurance, the policyholder pays up front and hopes the provider keeps its promise to make a payment in accordance with the contractual terms. For a tranche of society that probably has never used insurance products, trust is the element that should be created between the microinsurer and the prospective customer.

Policyholders do not generally trust that the insurer will pay the benefits in the event of a claim. The perceived insurance benefits are intangible to the customer, and would only become tangible after a claim was successfully lodged and paid out (Microinsurance Network, 2010). The typical microinsurance customer believes that premiums paid are wasted if he/she does not lodge a claim and receive payouts (Microinsurance Network, 2010). In addition, the market often perceives insurers as quick to take their money, but slow to settle the claim. A cumbersome aspect is that, due to low literacy levels, low-income market is often susceptible to fraudulent schemes, and resultantly undermining the credibility of legitimate insurers. Morsink (2012) after conducting her fields work in India, Kenya, the Philippines and Ethiopia further adds that people's confidence in insurance as a product is key to inducing them to take out a policy, and that microinsurance can actually help reduce poverty.

\subsection{Cost and Profitability}

While microfinance model based on micro lending can survive with a few clients, the same cannot be said for insurance offers in a micro scale, because it hampers with the basic Law of Large Numbers.

Since the premium charged is minimal, it is important that the law of large numbers prevails for the microinsurer to be able to pay up the transaction and administration costs and makes profits. In 2007, the costs of insurers to reach the low-income earners in the most remote places; villages, suburbs and locations were high, while their premiums to recover these costs are low (ASISA, 2013). The small policies increase the transactional costs of microinsurance products, and put pressure on the price of the policies.

\subsection{South Africa Microinsurance Regulatory Framework - A Microinsurance Act}

It is obvious that from the above challenges, very little has been done in the field of microinsurance in South Africa, Furthermore, research shows that there is no "Microinsurance Act" available in South Africa although there is a discussion paper under review. There are a number of motivations for developing a coherent microinsurance regulatory framework. These reflect both the needs to address particular problems and gaps in the current system as well as the need to facilitate the further development of the microinsurance market.

Research shows that more than two third of funeral cover are sold by informal burial societies that are not licensed by the relevant act and therefore is classified as an illegal business (National Treasury of South Africa, 2011). The market conduct regulation of microinsurance is primarily contained in the Financial Advisory and Intermediary Services Act (FAIS). The greater drive towards consumer protection embodied in the FAIS Act increases the per transaction cost of intermediating financial services, creating a disincentive to serve the lower-income and (hence lower revenue per premium) clients. Concerns about the potential consumer abuse in the low income market, combined with government's commitment under the charter to remove regulatory barriers to market development have prompted the National treasury (the policy-making body for the financial sector) to reconsider the insurance regulatory framework in South Africa (National Treasury of South Africa, 2011).

Furthermore, in 2007 the ILO together with the Bill and Melinda Gates Foundation have formed the Microinsurance Innovation Facility (MIF) for giving grants to developing countries including South Africa to develop further the microinsurance industry. The Old Mutual of South Africa is currently a member of the association (ILO, 2010). However, the absence of a coherent regulatory regime of microinsurance in place hinders the further development of the microinsurance market in South Africa while there is a population of approximately $61 \%$ of low-income market which are still untapped.

Despite the above problems and challenges posed to the low-income earners insurance, the full potential of microinsurance is only beginning to be grasped by stakeholders. The aim is not just to tackle the above - mentioned problems in theory but also to ensure that these challenges facing the microinsurance market are effectively addressed and implemented by the insurers and other relevant stakeholders. However, the main question is, what must insurers do to enable the growth of an affordable, cost effective and sustainable framework to entail an up-and-running MI industry in South Africa. It is obvious that from the above literature that $\mathrm{MI}$ is very important for the welfare of the country as a whole. The next section looks at some of the recommendations. 


\section{Recommendations}

\subsection{Improve financial literacy with regards to MI and financial knowledge of low-income earners}

FinScope South Africa (2013) has shown that there are still high levels of financial illiteracy in South Africa. It is a fact that knowledge of formal financial matters for instance, microinsurance products, is strongly linked to bringing down the level of poverty. Therefore special care needs to be taken that such people are carefully coached about financial matters. For instance, the relatively low growth in knowledge about the National Credit Act or planning for retirement or funeral is of some concern. Therefore financial education is in dire for low-income people.

\subsection{The publication of the new Microinsurance Act}

Micro-insurance as defined in the discussion paper is intended to "catalyse" the market provision of risk management tools for poor households. However, given the inherent complexity of insurance and the vulnerability of the target market, there are also risks of potential abuse and mis-selling. A balance therefore needs to be struck between market development and consumer protection.

Accordingly, the goal of the paper is to develop a coherent and clear regulatory framework that will encourage and facilitate the provision and distribution of good value, low-cost products that are appropriate to the needs of low-income consumers by a variety of market players, who must treat their policyholders fairly and manage the risks of providing insurance. This framework will not only bring down the regulatory unit costs in order to facilitate outreach into the lower income market by formal insurers but also provide formalisation and graduation options for the microinsurance market.

\subsection{Economies of scale}

In view of the nature and profile of a microinsurance policy bearing high costs, the profitability challenge in the microinsurance requires large volumes of very small policies. The transaction costs associated with managing these small policies can be extremely high, especially when seen in proportion to the sum assured

\subsection{The element of trust should be embedded in the low-income segment of the population}

Microinsurers need to find ways of convincing the target market that they are indeed trustworthy. Conventional insurers often try to create large, visible headquarters as a way to convey the impression that they are a large and stable firm. Located in the centres of towns and cities, the headquarters are often far from the areas where the poor live and work, which is not so useful for the low-income market. For Ml, perhaps the most effective way of conveying this message is through branding - associating the insurer with another firm that is trusted by the poor, for example when AIG entered the Indian market, a joint venture was formed with the Tata group of companies, one of the most trusted and respected industrial Indian conglomerates. Furthermore, the inclusion of pictorial posters, local folk arts and street theatres that explain the mechanisms of MI can be useful. Insurers should include the characteristics of the product design; lapsed policies, premium payment and claims processing delays in these visual marketing actions.

\section{Conclusion}

Both the primary and the secondary objectives have been addressed to investigate the MI industry in perspective. As a result, the paper reveals some important information about $\mathrm{Ml}$ and provides some recommendations in respect of the challenges posed to the industry.

\section{References}

Afrobarometer (2013). South Africa's poverty rate rise ahead of MDG benchmark year. Available at www.afrobarometer.org/files/ documents/ab_r5_policybriefno1.pdf

ASISA (Association for Savings and Investment South Africa) (2013). Research and Publications. Available at http://www.asisa.co.za/index.php/en/research-publications

Banerjee, A. (2008). Technology indispensable in marketing microinsurance accessible. Asia Insurance Review. Available at http://asiainsurancereview.com.

Banthia, A., Johnson, S., McCord, M. and Mathews, B. (2009).Microinsurance that works for Women: Making gender-sensitive Ml programs. Microinsurance Paper No 3. Geneva: International Labour Organisation. 
Brown, W and Churchill, C. (1999). Microinsurance: Providing Insurance to Low-Income Households. Part1: A Primer on Insurance Principles and Products. Microenterprises Best Practices

Churchill, C. and Matul, M. (2012). Protecting the Poor: A Micro Insurance Compendium Volume II. Geneva: International Labour Organisation.

Churchill, C. (2006). Protecting the Poor: A Micro Insurance Compendium Volume 1. Geneva: International Labour Organisation.

Cole, S., Stein, D. and Tobacman, J. (2011). What is a rainfall index insurance worth? A comparison of valuation techniques. Mimeo.

Dempsey, P. (2013). Media Release. Association for Savings and Investment South Africa. SA death and disability insurance shortfall increases to R24 trillion in 2013. Available at http://www.asisa.co.za/asisadocs/mediareleases/2013/20131113\% 20SA\%20death\%20and\%20disability\%20insurance\%20shortfall\%20increases\%20to\%20R24\%20trillion\%20in\%202013.pdf

De Witte, M. (2003). Money and death - Funeral business in Asante, Ghana. Journal of Africa, 73(4): 531-559.

Dong, H., De Allegri, M., Gnawali, D., Souares, A. and Sauerborn, R. (2009). Drop-out analysis of community-based health Insurance membership at Nouna, Berkina Faso. Health Policy, Vol. 92, pp 174-179.

FinScope South Africa (2013). Making Financial markets work for the poor. Available at http://www.finmark.org.za/event/launch-of-the-finscopesouth-africa-2013-survey-results/.

Gray, A. and Bel, S. 2010. New channels to get to the poor. Available at http://www.ilo.org/public/english/employment/mifacility/download/new_chan.pdf

Guarav, S., Cole, S. and Tobacman, J. (2011). Marketing complex financial products in emerging markets: Evidence from rainfall insurance in India. Journal of Marketing Research, Vol. 48, pp.150-162.

Hugo, F. (2013). The South African Insurance Gap. True South Actuaries and Consultants. Available at http://www.truesouth.co.za/index.php/thesouth-african-insurance-gap

Index Mundi (2013). South Africa Population. Available at http://www.indexmundi.com/south_africa/population.html

ILO (International Labour Organisation) (2012). Available at http://www.tribune.com.ng/news2013/index.php/en/business-package/2012-10-29-1136-27/insurance/item/4553-world-insurers-target-one-billion-micro-insurance-customers-by-2020.

ILO (International Labour Organisation) (2010). Microinsurance Innovation Facility's New Round of Innovation Grants Focuses on Scale and Efficiency. Available at http://www.ilo.org/public/english/employment/mifacility/media/press/scale_eff.htm.

IRR (Institute International Research) (2013). Available at http://microfinanceafrica.net/events/microinsurance-2013.

Loewe, M. (2001). Improving the social protection of urban poor and near-poor in Jordan. The potential of Microinsurance, Reports and Working Papers 12. Bonn German Development Institute.

Maleika, M. and Kuriakose, AT. (2012). Microinsurance : Extending Pro-Poor Risk Management through the Social Fund Platform. World Bank

Matul, M., Dalal, A., De Bock, O. and Gelade, W. 2013. Why people do not buy microinsurance and what can we do about it. Microinsurance paper no. 20. ISSN 2303-9191. Geneva: International Labour Organisation.

Mayoux, L (2002). Gender Dimensions of Microinsurance: Questioning the new bootstraps, Microinsurance: Improving risk management of the poor No. 7. Luxembourg: ADA.

McCord, M., Steinman, R., Ingram, M., Jaleran CT. and Mateo, M. 2012. Landscape of Microinsurance in Africa 2012. Munich Re Foundation.

Microinsurance Network (2013). Publications. Available at http://www.microinsurancenetwork.org/networkpublications.php

Microinsurance Network (2010). Providing insurance of real value to the poor. Available at http://www.microinsurancenetwork.org /file/Focus_12EN.pdf.

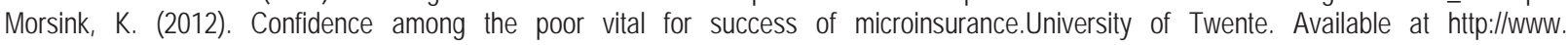
utwente.n//veiligheid/en/news/thesis_defence_morsink.doc/

Mulaudzi, R. (2014). Shack dweller .burnt beyond recognition. Available at http://www.enca.com/south-africa/shack-dweller-burnt-beyond-recognition. National Treasury of South Africa (2011). The South African Microinsurance Regulatory Framework. Available at microinsurance@treasury.gov.za.

Oxfam (2013). Available at https://www.oxfam.org.uk/what-we-do/countries-we-work-in/south-africa.

Oxfam GB (2012). Available at https://www.oxfam.org.uk/what-we-do/countries-we-work-in/uk

Plateau, JP, and Uggarte, D. (2013). Understanding and information failures: Lessons from a health microinsurance programs in India. Research Paper No 29, Microinsurance Innovation Facility. Geneva: International Labour Organisation.

Reinhard, D. (2012). Microinsurance coverage expanding at breathtaking pace. Geneva: International Labour Organisation and the Munich Re Foundation.

Smith, A., Chamberlain, D., Hougaard, C., Carlman, J. and Smit, H. (2010). Making financial markets work for the poor. Reaching the client. Update on microinsurance innovation in South Africa. Available http://www.cenfri.org/documents/microinsurance/2010/ Update\%20on\%20innovation\%202010/Update\%20on\%20innovation_Synthesis\%20note.pdf.

Stats SA (Statistics South Africa) (2013). Statistical Release P0302. Mid-year population estimates 2013. Available at http://beta2.statssa.gov.za/publications/P0302/P03022013.pdf

Stats SA (Statistics South Africa) (2011). Statistical Release P0310. Living Conditions of Households in SA. Available at http://www.statssa.gov.za/publications/P0310/P03102008.pdf

Swiss Re 2011. World Insurance in 2011. Sigma No 3/2012. Swiss Re.

Tomchinsky, G. (2008). Introduction to Microinsurance Historical Perspective". A paper presented at $4^{\text {th }}$ International Micro Insurance Conference. Held at Cartagena Columbia on $5^{\text {th }}$ November 2008.

UNDP (United Nations Development Programme) (2013) MDGs (Millennium Development Goals) (2013). South Africa Country Report 2013. Republic of South Africa.

UNDP (United Nations Development Programme) (2005). Millennium Development Goals (MDGs). Available at http://www. undp.org/mdg/basics.html.

UNIFEM (United Nations Entity for Gender Equality and the Empowerment of Women) 2010. Available at http://unwomen-nc.org.sg/gender_ issues_datasheet_l.shtml.

UNEP FI (United Nations Environment Programme Finance Initiative) (2008). Available at http://www.environmental-finance.com/ onlinews/0524ins.htm.

World Bank (2012). Data. World Development indicators 2012. Available at data.worldbank.org.

World Bank (2010). Data and Research. Global Monitoring Report 2013: Monitoring the MDGs. World Bank. 